\title{
THE IMPACT OF CORPORATE GOVERNANCE ON FINANCIAL PERFORMANCE OF LEBANESE BANKS
}

\author{
Bilal Jibai \\ Lebanese International University, Beirut, Lebanon
}

The aim of this research is to study the impact of corporate governance disclosure on the financial performance of Lebanese banks. The impacts of corporate governance consequences on financial performance are the problem being faced by many firms. This research applies a quantitative methodology to the data from 29 banks' annual reports for the year 2018. This data was analyzed using regression analysis means. This empirical study intends to find substantial evidence which would help acquire new knowledge and better understanding of how virtuous corporate governance practices and disclosures may help improve banks' performance. In particular, validation of our research hypotheses may help with assessing the importance of corporate governance disclosure for the financial performance of Lebanese banks. The research proves there is a direct relationship between diversity on board and financial performance, as well as, between frequency of Board meetings and financial performance.

Keywords: corporate governance, financial performance, bank's Board, Lebanese banking sector

\section{Introduction}

The aim of this research is to study the impact of corporate governance disclosure on the financial performance of various Lebanese banks. Corporate governance has been an important research area, it essentially deals with different management arrangements employed to manage business activities and maximize shareholders' wealth. The importance of this is exposed in numerous literature sources mentioned in the literature review, while our research questions directly concern the intricate relations between owners and management.

The Basel Committee on Banking Supervision (2003) concluded that good corporate governance prohibits administrators from expropriating bank's wealth, thus ensuring sound

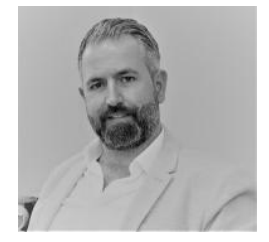

Bilal Jibai

Ph.D., Assistant Professor

Assistant Dean- School of Business, Lebanese International University, Lebanon

Research interests: financial market, banking, bank marketing, customer behavior

Email: bilal.jibai@liu.edu.lb 
decision-making and efficient management. In the longer term, this leads to better sales and improved performance of bank capital.

\section{Significance of the study}

Corporate governance is considered to be of utmost importance for any country to experience sustainable growth. Significant benefits like low capital cost, access to external financing and better firm performance are often associated with high ethics of corporate governance within the private sector. Gradual depreciation of various dimensions within corporate governance leads to lower financial performance, and this is the problem faced by various firms across almost all economic sectors.

In developing countries, the research on corporate governance is rather scarce, even these days. Even though the consumer service sector is playing a very important role in social and economic development of these countries, corporate governance is still poorly understood and many specific governance issues remain to be unexplored. Given the role of the corporate sector in Lebanon, it would be important and quite appropriate to scrutinize the consequences of corporate governance for the financial performance of Lebanese banking sector.

Little attention has been paid so far to the governance needs of this sector and to studying the consequences of corporate governance for enterprises performance. This study would bridge in the research gap and provide new insights into this field. On the academic side, this will be a contribution to the knowledge on corporate governance, its disclosure and their consequences for banks' financial performance.

\section{Agency Theory}

This theory has been actively developed by Alexander (2006) covering subjects' relative to corporate governance and is the result of control and ownership separation. Due to technical limitations, like insufficient capital and the managerial experience required to manage funds, investors hire managers to get virtuous returns, and in return, managers are rewarded for their services.

As managers' actions (and inactions) do not always turn out to be financially beneficial (some might actually prove harmful), this may result in the agency problem. Therefore, as defined by (Caprio et al, 2007), agency problem emphasizes on the privilege used by managers. Interestingly, managers find themselves entrenched in their position at the same time. Even if managers are not qualified to run the firm, they can take hold by establishing themselves in other ways (Chidambaran et al., 2008).

This helps the firm to position, for example, family members on main managerial positions, thus overpaying the executives and using the earned profit to get benefits for themselves (and the family) instead of paying off to investors. Therefore, as a result of selfcentered managers, there would be an agency loss to outstanding applicants and the owners would experience more losses than in the case when they directly exercise control over the organization in their ownership.

The solution to this cost problem directly associated with the agency involves accepting certain costs of the agency. These costs come in the shape of either sanctions, or incentives, thus aligning the interests of executives with those of shareholders. 


\section{THE IMPACT OF CORPORATE GOVERNANCE}

Henceforth, the corporate governance principles control external and internal executive practices via internal and external regulating methods which monitor them directly and/or bring in line with shareholders' interests.

In this situation, interest struggle is observed between the controlling shareholders, the minority shareholders and the managers. In such a case, the latter might overuse perks from the internal resources and thus might become not that much interested to continue profitgenerating activities.

Monitoring expenses such as budgeting, compensation systems, auditing and control, bonding expenditures are all included in the agency costs. Significant losses in part of these expenses may cause the interest deviation between the agent and the principal. Such agency costs are dictated by the share price which the shareholders pay. Hence, to have an increase in a firm's value, the agency costs must be reduced.

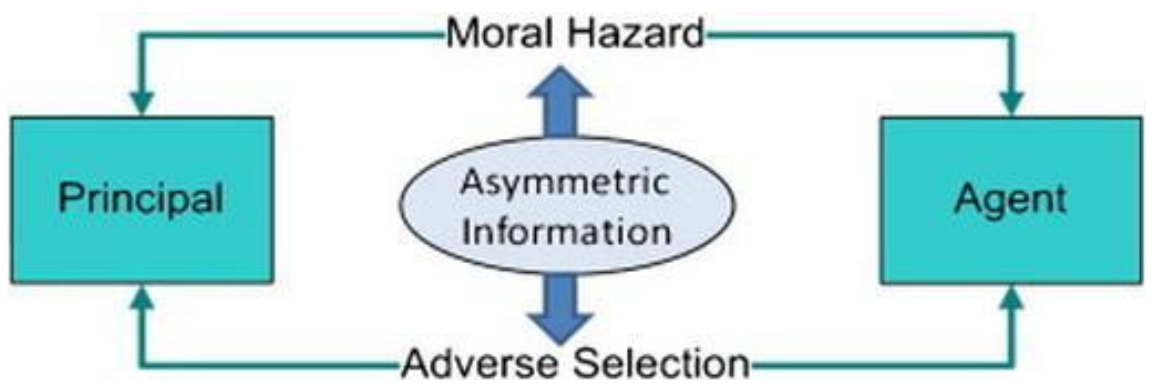

Figure 1. Principal/Agency Problem Framework

(Source: Tarullo, 2012)

\section{Asymmetric Information}

This problem occurs when a conflict between directors and owners is growing. When the latter perceive agent's action as imperfect and as a mismatch to own interests/intentions, the asymmetric information occurs.

Moral hazard and adverse selection are two different terms which are used in risk management studies to describe situations where one party is at a disadvantage.

When there is asymmetric information between two parties and a change in the behavior of one party, this is called a moral hazard. Adverse selection occurs when there is a lack of symmetric information prior to a deal between executives and the owner. Asymmetric information (which is also sometimes called information failure) happens when one party to a transaction has greater knowledge than the other party.

Moral hazard occurs when a party that has agreed to a transaction is providing misleading information or changes their behavior because they believe that they won't have to face any consequences for their actions.

Adverse selection describes a situation in which one party in a deal has more accurate and different information than the other party. The party with less information is at a disadvantage to the party with more information. This asymmetry causes a lack of efficiency in the price and quantity of goods and services. Most information within the market economy is transferred through prices, which means that adverse selection tends to result from ineffective price signals. 


\section{Empirical Literature Review}

The first global investor opinion survey was organized back in 2000 and had over 200 institutional investors included. Adams \& Mehran (2008) confirmed that $80 \%$ of its respondents stated that they are ready to pay premium for well-governed firms. A wellgoverned firm was defined as one having no management ties, mostly outside directors, was receptive to investors' demands for information on governance issues and also had mostly external directors.

Another study was conducted over a period of five years, it concentrated on the most admired firms according to the Fortune magazine data. Amit \& Villonga (2006) stated that these "most admired" firms return $125 \%$ on average, whereas the "least esteemed" firms had an $80 \%$ average return.

In an alternative study organized by Business Week, they made a list of institutional investors and "experts" to help in distinguishing between the boards with virtuous and immoral governance. The study found that thanks to good governance firms claiming upper rankings also had maximum economic returns.

On numerous occasions other researchers evaluated the consequence of corporate governance on financial performance of firms from various sectors. In our review we present only a fraction from this research volume.

Consequences of corporate governance for the financial performance of Ethiopian private banks were analyzed by the Basel Committee On Banking Supervision (2006). Namely, it was observed that liquidity ratio and gender diversity do not have substantial influence on banks' financial performance. However, educational qualification of the board members is directly correlated with the selected banks' performance. Besides this, frequency of board meetings, number of sub-committees and boards ownership also affect banks' performance.

Investigation carried out by (Williams, 2012) on the performance of Jordan's 27 insurance companies and the consequences from their corporate governance dimensions' pointed to the existence of a constructive association between external ownership and corporate governance elements. Separation of a Chair and a CEO roles indicates there is an adverse relationship between them and the performance.

Van Osnabrugge (2000) studied the consequence of corporate governance on firms' performance in the case with 171 Saudi Arabian companies listed at the local stock exchange, 2012 to 2014. As per the results of this study, there was a noteworthy significance found from the board size and ownership form for the firms' performance.

An experiential study on Vietnam's 177 listed firms was carried out by Turner (2009). This author studied the relationship between corporate governance and firm performance with the dual CEO role, board independence, ownership absorption and board size as the independent variables. Positive correlation was found between firm's performance and dual CEO role. Organizational change between firm's performance and managerial ownership was also found as well as the fact that independence of the board tends to have a reverse impact on firm's performance. No noteworthy relationship was detected however between board size and performance. 


\section{THE IMPACT OF CORPORATE GOVERNANCE}

\section{Board Size and Firm Performance}

The board of directors may obstruct the propensity of executives to follow their selfregarding plans. This is frequently explained through the prism that the size of a board is an essential factor. Larger boards usually can provide much broader monitoring over management. There is a positive correlation between firm's quality or board size, as proven by Trayler (2007).

Previous research has shown that both larger and smaller boards have their advantages and disadvantages. Some authors have analyzed the correlation between insolvency and board size and suggested that non-failed companies appear to have bigger boards as compared to the failed companies within the same sample (Taylor, 2006).

\section{Board Meeting Frequency and Firm Performance}

The number of board meetings may indirectly measure the participation of executives in the management process. However, it does not necessarily indicate whether an executive is really aggressively contributing to the conversation inside the board. The major role of the boards of directors, as stated previously, is to control management. This is because managers are believed to be self-interested or prone to a moral risk. Higher frequency of board meetings may actually help with better tracking of managerial activities so that it is in line with the initial goals of the investors.

This would possibly diminish issues inside the company overall and improve business performance. The number of board meetings may become a significant source of productivity, as argued by Tarullo (2012).

A reasonably efficient number of meetings between management and boards of directors will promote the collaboration between various members of management. This may also improve the efficiency of the board itself. The number of meetings is frequently utilized as a reference when monitoring and/or assessing the board's operations. Hence, the board meetings frequency will also be taken into account in our empirical research.

\section{Role Duality and Firm Performance}

Role duality arises when one person, namely a CEO and a Chairman, holds these two leading positions in a company at the same time. CEO is always considered to be a full-time position since it is directly related to the daily process of development and implementation of a corporate strategy. On the other hand, the chairman's key role is to assess and monitor the performance of various managerial officers, including CEO. Thus, an entity holding both these important roles is more probable to demonstrate their individual attention to the company's key difficulties (Toçi, 2008).

In theory, there are two different observations regarding the duality of these two roles based on the stewardship theory or the agency theory. Some researchers and practitioners claim that to control the $\mathrm{CEO}$ and the executive board, the chairman must be fully independent. Therefore, this theory insists on the necessity to separate these two functions. Separation, in this context, is essential to ensure that the quality of management is timely reviewed and well balanced. 


\section{Methodology}

\section{Population of the Study}

This research study relies on secondary data from the banks' annual reports for the year 2018. The data was available directly on the banks' websites. The sample of 29 banks was selected using convenient sampling, out of 49 commercial banks accredited and licensed by the Central Bank of Lebanon. These banks can also be classified as indigenous and institutionally owned banks.

\section{Sampling Techniques}

The researcher used the convenience sampling technique to collect the data from the selected banks in order to study the impact of corporate governance disclosure on the financial performance of Lebanese banks.

\section{Data Collection Tools}

The study has adopted a method involving quantitative resources. The use of quantitative research methods has helped us to assess the importance of corporate governance disclosure and its impact on the financial performance of the 29 banks in question and also to prove the research hypotheses.

The data obtained from the banks' annual reports was categorized as qualitative and quantitative. The board size, frequency of board meetings and ROAA were entered as absolute values. The independent members on boards were entered as percentages. Afterwards, the percentages of the latter variable were taken on the scale of 1 to 5 respectively as follows ( $0 \%$ to $20 \%, 20 \%$ to $40 \%, 40 \%$ to $60 \%, 60 \%$ to $80 \%$ and $80 \%$ to $100 \%$ ) in order to insert them into the SPSS as dummy variables. Several other dummy variables were taken into consideration including the duality of roles, committees, CSR, culture, and diversity on board.

Since the mentioned variables are extracted from the annual reports in a qualitative way (choosing Yes or No answers), they are coded as $(1=$ disclosed and $0=$ not disclosed) to be able to conduct the regression analysis later. Dummy variables have been used to replace the encoded categorical variables to some numeric values (generally represented by 0 and 1). The dummy variables act here like "switches" that turn various parameters in an equation on and off.

Additionally, high-quality academic peer-reviewed journals, books, articles, Internet websites, and corporate reports suitable for this study were evaluated and explored. This documentary database was used as a secondary source of information to analyze the banks' corporate governance practices and varied financial performance.

Considering the objectives of our study, the researcher intends to validate the hypotheses by means of adopting different statistical techniques, including regression analysis and Pearson correlations. These tests were generated using SPSS. 
THE IMPACT OF CORPORATE GOVERNANCE

\section{Research Model}

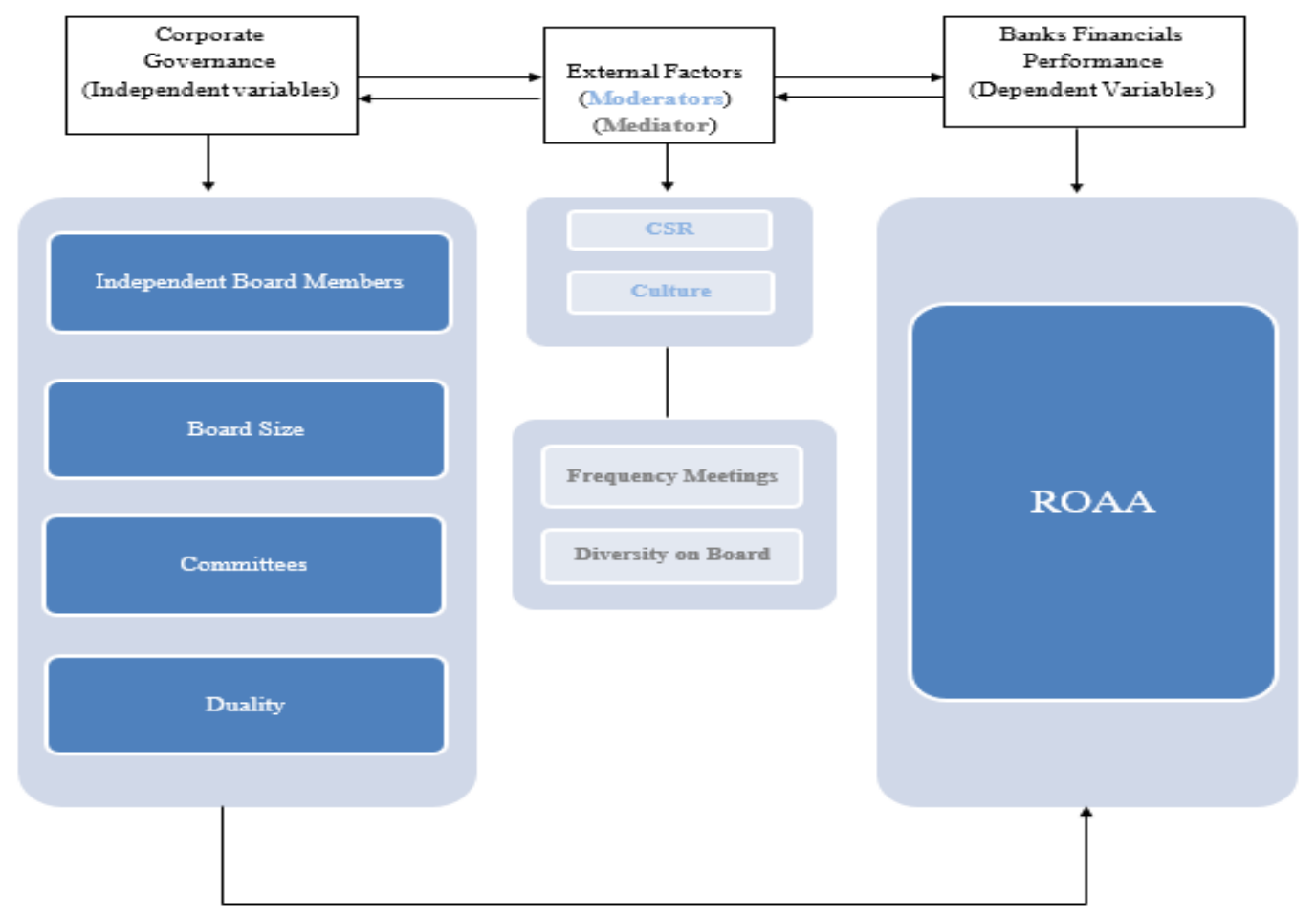

Figure 2 - Research Model

(Source: Developed and designed by the author)

The first column in the above model shows the corporate governance variables collected from the annual reports of the studied banks. These variables are independent ones. The second column shows the external factors that affect either independent, dependent or both groups of variables. The moderators (culture and corporate social responsibility) and the mediators (frequency of meetings and diversity on board) are also included in the model.

The moderating variables play an important role in strengthening the relation between dependent and independent variables. The better the CSR practices in a firm, the better the firm's financial performance. Same may be applicable for the factor of culture since it plays a similar role - it simplifies stakeholders' interaction with the bank and their acceptance (or rejection) of the corporate governance as well as their interest in the disclosure of information.

Talking about the mediators (the second raw under the external factors) it is important to keep in mind that those potential mechanism factors have a major effect on the independent variables. As it was proved by previous researchers, the frequency of meetings and diversity on board (including the gender) has a lot to do with the board of directors' decisions, thus influencing corporate performance.

Finally, ROAA (see the last column) covers the dependent variables. These numbers are known to be the major indicators of firm's performance. 


\section{Regression Analysis}

This section addresses three different regression analyses of the research variables. The first regression has been performed for all the variables. The variables that show multicollinearity will be removed to maintain low VIF and avoid multicollinearity.

\section{Regression and Collinearity}

Table 2 - Regression Analysis

(Source: Developed and designed by the author)

\begin{tabular}{|c|c|c|c|c|c|c|c|c|c|c|}
\hline & & 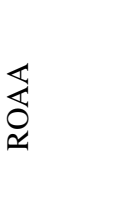 & 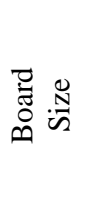 & $\begin{array}{l}\stackrel{\mathscr{E}}{\mathscr{\Xi}} \\
\text { : }\end{array}$ & 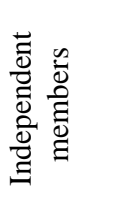 & $\stackrel{\stackrel{\Xi}{\Xi}}{\Xi}$ & $\frac{x}{3}$ & 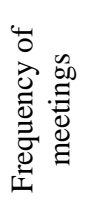 & 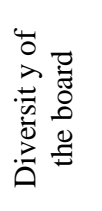 & 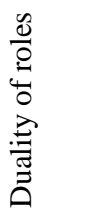 \\
\hline \multirow{9}{*}{ 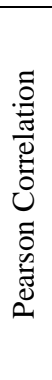 } & ROAA & 1.000 & .347 & -.055 & .194 & -.003 & -.012 & .284 & -.341 & -.206 \\
\hline & $\begin{array}{c}\text { Board } \\
\text { Size }\end{array}$ & .347 & 1.000 & .196 & .073 & .025 & -.407 & .098 & .034 & .089 \\
\hline & Committee & -.055 & .196 & 1.000 & .062 & .089 & -.012 & .403 & .701 & .751 \\
\hline & Independent & .194 & .073 & .062 & 1.000 & .197 & .292 & .285 & -.007 & .070 \\
\hline & Culture & -.003 & .025 & .089 & .197 & 1.000 & -.139 & -.289 & -.009 & .009 \\
\hline & CSR & -.012 & -.407 & -.012 & .292 & -.139 & 1.000 & .244 & -.188 & -.153 \\
\hline & Frequency & .284 & .098 & .403 & .285 & -.289 & .244 & 1.000 & .389 & .409 \\
\hline & Diversity & -.341 & .034 & .701 & -.007 & -.009 & -.188 & .389 & 1.000 & .933 \\
\hline & Duality & -.206 & .089 & .751 & .070 & .009 & -.153 & .409 & .933 & 1.000 \\
\hline \multirow{9}{*}{ 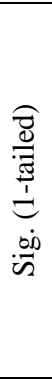 } & ROAA & - & .033 & .388 & .157 & .494 & .476 & .068 & .035 & .142 \\
\hline & $\begin{array}{c}\text { Board } \\
\text { Size }\end{array}$ & .033 & . & .154 & .353 & .449 & .014 & .307 & .431 & .323 \\
\hline & Committee & .388 & .154 & . & .375 & .323 & .475 & .015 & .000 & .000 \\
\hline & Independent & .157 & .353 & .375 & - & .153 & .062 & .067 & .487 & .360 \\
\hline & Culture & .494 & .449 & .323 & .153 & . & .236 & .064 & .481 & .481 \\
\hline & CSR & .476 & .014 & .475 & .062 & .236 & . & .101 & .164 & .214 \\
\hline & Frequency & .068 & .307 & .015 & .067 & .064 & .101 & . & .019 & .014 \\
\hline & Diversity & .035 & .431 & .000 & .487 & .481 & .164 & .019 & . & .000 \\
\hline & Duality & .142 & .323 & .000 & .360 & .481 & .214 & .014 & .000 & \\
\hline \multirow{9}{*}{ Z } & ROAA & 29 & 29 & 29 & 29 & 29 & 29 & 29 & 29 & 29 \\
\hline & Board_Size & 29 & 29 & 29 & 29 & 29 & 29 & 29 & 29 & 29 \\
\hline & Committee & 29 & 29 & 29 & 29 & 29 & 29 & 29 & 29 & 29 \\
\hline & Independent & 29 & 29 & 29 & 29 & 29 & 29 & 29 & 29 & 29 \\
\hline & Culture & 29 & 29 & 29 & 29 & 29 & 29 & 29 & 29 & 29 \\
\hline & CSR & 29 & 29 & 29 & 29 & 29 & 29 & 29 & 29 & 29 \\
\hline & Frequency & 29 & 29 & 29 & 29 & 29 & 29 & 29 & 29 & 29 \\
\hline & Diversity & 29 & 29 & 29 & 29 & 29 & 29 & 29 & 29 & 29 \\
\hline & Duality & 29 & 29 & 29 & 29 & 29 & 29 & 29 & 29 & 29 \\
\hline
\end{tabular}

The above collinearity test aims to study whether there is high multicollinearity among the variables or not. Most of the Pearson coefficients here have the level below 0.75 but for two variables which are duality of roles and diversity on board. 


\section{THE IMPACT OF CORPORATE GOVERNANCE}

Table 2 - Regression Analysis

(Source: Developed and designed by the author)

\begin{tabular}{|l|r|r|r|c|}
\hline Model & $\mathrm{R}$ & $\mathrm{R}$ Square & $\begin{array}{c}\text { Adjusted R } \\
\text { Square }\end{array}$ & $\begin{array}{c}\text { Std. Error of the } \\
\text { Estimate }\end{array}$ \\
\hline 1 & $.704^{\mathrm{a}}$ & .495 & .294 & .34133 \\
\hline
\end{tabular}

a. Predictors: (Constant), Duality, Culture, Board Size, Independent, CSR,

Frequency, Committee, Diversity.

\begin{tabular}{|c|c|c|c|c|c|c|c|c|c|c|c|}
\hline \multicolumn{12}{|c|}{ Coefficients } \\
\hline \multirow{2}{*}{\multicolumn{2}{|c|}{ Model }} & \multicolumn{2}{|c|}{$\begin{array}{l}\text { Unstandardized } \\
\text { Coefficients }\end{array}$} & \multirow{2}{*}{$\begin{array}{c}\begin{array}{c}\text { Standa } \\
\text { r-dized } \\
\text { Coeffi } \\
\text {-cients }\end{array} \\
\text { Beta }\end{array}$} & \multirow[t]{2}{*}{$\mathrm{t}$} & \multirow[t]{2}{*}{ Sig. } & \multicolumn{3}{|c|}{ Correlations } & \multicolumn{2}{|c|}{$\begin{array}{l}\text { Collinearity } \\
\text { Statistics }\end{array}$} \\
\hline & & B & $\begin{array}{l}\text { Std. } \\
\text { Error }\end{array}$ & & & & $\begin{array}{l}\text { Zero- } \\
\text { order }\end{array}$ & Partial & Part & $\begin{array}{l}\text { Tole- } \\
\text { rance }\end{array}$ & VIF \\
\hline \multirow{9}{*}{1} & (Constant) & -.220 & .554 & & -.397 & .695 & & & & & \\
\hline & Board_Size & .135 & .138 & .191 & .977 & .340 & .347 & .213 & .155 & .662 & 1.510 \\
\hline & Committee & .070 & .222 & .083 & .314 & .757 & -.055 & .070 & .050 & .360 & 2.774 \\
\hline & Independent & .006 & .069 & .017 & .088 & .930 & .194 & .020 & .014 & .705 & 1.418 \\
\hline & Culture & .144 & .289 & .091 & .497 & .625 & -.003 & .110 & .079 & .749 & 1.336 \\
\hline & CSR & -.184 & .210 & -.187 & -.874 & .393 & -.012 & -.192 & -.139 & .553 & 1.807 \\
\hline & Frequency & .161 & .065 & .523 & 2.490 & .022 & .284 & .486 & .395 & .571 & 1.752 \\
\hline & Diversity & -.920 & .372 & -1.152 & -2.472 & .023 & -.341 & -.484 & -.393 & .116 & 8.608 \\
\hline & Duality & .436 & .390 & .545 & 1.116 & .278 & -.206 & .242 & .177 & .106 & 9.463 \\
\hline
\end{tabular}

The above regression analysis proves that there is a significant relationship between frequency (0.022), diversity on the board (0.023) and ROAA since the significance level is below 5\%. Then, we perform the VIF test which aims to study whether there is multicollinearity between the tested variables or not.

The VIF ratio indicates the level of 8.608 and 9.463 for both duality and diversity respectively which are considered to be very high ratios and might affect the whole model.

This means that one of these variables should be removed due to multicollinearity among them. The researcher opted to remove the duality factor and conduct another regression to avoid multicollinearity and study how the regression model will be then affected. 
Table 3 - Collinearity Analysis

(Source: Developed and designed by the author)

\begin{tabular}{|c|c|c|c|c|c|c|c|c|c|}
\hline \multicolumn{10}{|c|}{ Correlations } \\
\hline & & ROAA & $\begin{array}{c}\text { Board__ } \\
\text { Size }\end{array}$ & $\begin{array}{c}\text { Commit- } \\
\text { tee }\end{array}$ & $\begin{array}{c}\text { Indepen- } \\
\text { dency }\end{array}$ & $\begin{array}{l}\text { Cultu- } \\
\text { re }\end{array}$ & CSR & $\begin{array}{c}\text { Frequen- } \\
\text { cy }\end{array}$ & $\begin{array}{c}\text { Diversi } \\
\text {-ty }\end{array}$ \\
\hline \multirow{8}{*}{ 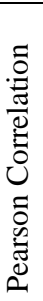 } & ROAA & 1.000 & .347 & -.055 & .194 & -.003 & -.012 & .284 & -.341 \\
\hline & Board_Size & .347 & 1.000 & .196 & .073 & .025 & -.407 & .098 & .034 \\
\hline & Committee & -.055 & .196 & 1.000 & .062 & .089 & -.012 & .403 & .701 \\
\hline & Independency & .194 & .073 & .062 & 1.000 & .197 & .292 & .285 & -.007 \\
\hline & Culture & -.003 & .025 & .089 & .197 & 1.000 & -.139 & -.289 & -.009 \\
\hline & CSR & -.012 & -.407 & -.012 & .292 & -.139 & 1.000 & .244 & -.188 \\
\hline & Frequency & .284 & .098 & .403 & .285 & -.289 & .244 & 1.000 & .389 \\
\hline & Diversity & -.341 & .034 & .701 & -.007 & -.009 & -.188 & .389 & 1.000 \\
\hline \multirow{8}{*}{ 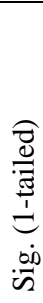 } & ROAA & & .033 & .388 & .157 & .494 & .476 & .068 & .035 \\
\hline & Board_Size & .033 & . & .154 & .353 & .449 & .014 & .307 & .431 \\
\hline & Committee & .388 & .154 & . & .375 & .323 & .475 & .015 & .000 \\
\hline & Independency & .157 & .353 & .375 & $\cdot$ & .153 & .062 & .067 & .487 \\
\hline & Culture & .494 & .449 & .323 & .153 & & .236 & .064 & .481 \\
\hline & CSR & .476 & .014 & .475 & .062 & .236 & . & .101 & .164 \\
\hline & Frequency & .068 & .307 & .015 & .067 & .064 & .101 & & .019 \\
\hline & Diversity & .035 & .431 & .000 & .487 & .481 & .164 & .019 &. \\
\hline \multirow[b]{8}{*}{ Z } & ROAA & 29 & 29 & 29 & 29 & 29 & 29 & 29 & 29 \\
\hline & Board_Size & 29 & 29 & 29 & 29 & 29 & 29 & 29 & 29 \\
\hline & Committee & 29 & 29 & 29 & 29 & 29 & 29 & 29 & 29 \\
\hline & Independency & 29 & 29 & 29 & 29 & 29 & 29 & 29 & 29 \\
\hline & Culture & 29 & 29 & 29 & 29 & 29 & 29 & 29 & 29 \\
\hline & CSR & 29 & 29 & 29 & 29 & 29 & 29 & 29 & 29 \\
\hline & Frequency & 29 & 29 & 29 & 29 & 29 & 29 & 29 & 29 \\
\hline & Diversity & 29 & 29 & 29 & 29 & 29 & 29 & 29 & 29 \\
\hline
\end{tabular}

The above test had been repeated after removing the duality variable from the model because it had high VIF and demonstrated multicollinearity. The above table indicates that there is multicollinearity between diversity and committee which will be explained later on, in another regression.

Table 4 - Regression Analysis and VIF

(Source: Developed and designed by the author)

\begin{tabular}{|c|c|c|c|c|}
\hline \multicolumn{5}{|c|}{ Model Summary } \\
\hline Model & $\mathrm{R}$ & R Square & $\begin{array}{c}\text { Adjusted R } \\
\text { Square }\end{array}$ & $\begin{array}{c}\text { Std. Error of the } \\
\text { Estimate }\end{array}$ \\
\hline 1 & $.681^{\mathrm{a}}$ & .464 & .285 & .34332 \\
\hline \multicolumn{3}{|c|}{ a. Predictors: (Constant), Diversity, Independency, Board_Size, Culture, CSR, } \\
Frequency, Committee.
\end{tabular}




\section{THE IMPACT OF CORPORATE GOVERNANCE}

\begin{tabular}{|c|c|c|c|c|c|c|c|c|c|c|c|}
\hline \multicolumn{12}{|c|}{ Coefficients $^{\mathrm{a}}$} \\
\hline \multirow{2}{*}{\multicolumn{2}{|c|}{ Model }} & \multicolumn{2}{|c|}{$\begin{array}{c}\text { Unstandardized } \\
\text { Coefficients }\end{array}$} & \multirow{2}{*}{$\begin{array}{c}\begin{array}{c}\text { Standardi- } \\
\text { zed } \\
\text { Coefficients }\end{array} \\
\text { Beta }\end{array}$} & \multirow[t]{2}{*}{$\mathrm{T}$} & \multirow[t]{2}{*}{ Sig. } & \multicolumn{3}{|c|}{ Correlations } & \multicolumn{2}{|c|}{$\begin{array}{c}\text { Collinearity } \\
\text { Statistics }\end{array}$} \\
\hline & & B & $\begin{array}{l}\text { Std. } \\
\text { Error }\end{array}$ & & & & $\begin{array}{l}\text { Zero- } \\
\text { order }\end{array}$ & Partial & Part & $\begin{array}{c}\text { Tolera } \\
\text { nce }\end{array}$ & VIF \\
\hline & (Constant) & -.253 & .557 & & -.455 & .654 & & & & & \\
\hline & Board_Size & .141 & .139 & .198 & 1.011 & .324 & .347 & .215 & .162 & .663 & 1.508 \\
\hline & Committee & .153 & .210 & .183 & .729 & .474 & -.055 & .157 & .116 & .407 & 2.458 \\
\hline 1 & $\begin{array}{l}\text { Independen } \\
\mathrm{t}\end{array}$ & .020 & .068 & .055 & .293 & .773 & .194 & .064 & .047 & .729 & 1.372 \\
\hline & Culture & .131 & .291 & .083 & .450 & .658 & -.003 & .098 & .072 & .750 & 1.333 \\
\hline & CSR & -.193 & .211 & -.196 & -.914 & .371 & -.012 & -.196 & -.146 & .554 & 1.804 \\
\hline & Frequency & .161 & .065 & .525 & 2.482 & .022 & .284 & .476 & .397 & .571 & 1.752 \\
\hline & Diversity & -.571 & .203 & -.715 & -2.809 & .011 & -.341 & -.523 & -.449 & .394 & 2.539 \\
\hline
\end{tabular}

This newer round of the regression analysis had been conducted after removing the duality variable from the model and the results prove that meetings frequency and diversity are still significant for ROAA, (0.022) and (0.011) respectively.

This means that the null hypotheses are rejected and the alternative hypothesis is accepted.

However, referring to VIF, the committee and the diversity variables show moderate multicollinearity, meaning that there is a moderate correlation among them.

The committee variable will be now removed from the model, and another regression analysis will be conducted to study how the model will be affected in this case.

Table 5 - Collinearity Analysis

(Source: Developed and designed by the author)

\begin{tabular}{|c|c|c|c|c|c|c|c|c|}
\hline & & ROAA & $\begin{array}{c}\text { Board } \\
\text { Size }\end{array}$ & $\begin{array}{c}\text { Indepen } \\
\text { dent }\end{array}$ & $\begin{array}{l}\text { Cultu- } \\
\text { re }\end{array}$ & CSR & $\begin{array}{c}\text { Frequen- } \\
\text { cy }\end{array}$ & Diversity \\
\hline \multirow{7}{*}{ 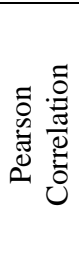 } & ROAA & 1.000 & .347 & .194 & -.003 & -.012 & .284 & -.341 \\
\hline & Board Size & .347 & 1.000 & .073 & .025 & -.407 & .098 & .034 \\
\hline & Independent & .194 & .073 & 1.000 & .197 & .292 & .285 & -.007 \\
\hline & Culture & -.003 & .025 & .197 & 1.000 & -.139 & -.289 & -.009 \\
\hline & CSR & -.012 & -.407 & .292 & -.139 & 1.000 & .244 & -.188 \\
\hline & Frequency & .284 & .098 & .285 & -.289 & .244 & 1.000 & .389 \\
\hline & Diversity & -.341 & .034 & -.007 & -.009 & -.188 & .389 & 1.000 \\
\hline \multirow{7}{*}{ 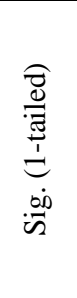 } & ROAA & . & .033 & .157 & .494 & .476 & .068 & .035 \\
\hline & $\begin{array}{l}\text { Board } \\
\text { Size }\end{array}$ & .033 & . & .353 & .449 & .014 & .307 & .431 \\
\hline & Independent & .157 & .353 & . & .153 & .062 & .067 & .487 \\
\hline & Culture & .494 & .449 & .153 & . & .236 & .064 & .481 \\
\hline & CSR & .476 & .014 & .062 & .236 & $\cdot$ & .101 & .164 \\
\hline & Frequency & .068 & .307 & .067 & .064 & .101 & . & .019 \\
\hline & Diversity & .035 & .431 & .487 & .481 & .164 & .019 & . \\
\hline \multirow{7}{*}{ Z } & ROAA & 29 & 29 & 29 & 29 & 29 & 29 & 29 \\
\hline & $\begin{array}{l}\text { Board } \\
\text { Size }\end{array}$ & 29 & 29 & 29 & 29 & 29 & 29 & 29 \\
\hline & Independent & 29 & 29 & 29 & 29 & 29 & 29 & 29 \\
\hline & Culture & 29 & 29 & 29 & 29 & 29 & 29 & 29 \\
\hline & CSR & 29 & 29 & 29 & 29 & 29 & 29 & 29 \\
\hline & Frequency & 29 & 29 & 29 & 29 & 29 & 29 & 29 \\
\hline & Diversity & 29 & 29 & 29 & 29 & 29 & 29 & 29 \\
\hline
\end{tabular}


In the above model, the committee has been removed from the model because of high multicollinearity and high VIF indicator. According to the above table, all the variables have a low multicollinear level since all the coefficients are below 0.7. This indicates a low to medium multicollinearity level.

Table 6 - Regression Analysis and VIF

(Source: Developed and designed by the author)

\begin{tabular}{|c|c|c|c|c|}
\hline \multicolumn{5}{|c|}{ Model Summary } \\
\hline Model & $\mathrm{R}$ & R Square & $\begin{array}{c}\text { Adjusted R } \\
\text { Square }\end{array}$ & $\begin{array}{c}\text { Std. Error of the } \\
\text { Estimate }\end{array}$ \\
\hline 1 & $.671^{\mathrm{a}}$ & .450 & .300 & .33965 \\
\hline \multicolumn{5}{|c|}{ a. Predictors: (Constant), Diversity, IND3, Board Size, Culture, CSR, Frequency } \\
\hline
\end{tabular}

\begin{tabular}{|c|c|c|c|c|c|c|c|c|c|c|c|}
\hline \multicolumn{2}{|c|}{ Model } & \multicolumn{2}{|c|}{$\begin{array}{c}\text { Unstandardized } \\
\text { Coefficients }\end{array}$} & $\begin{array}{c}\begin{array}{c}\text { Standardized } \\
\text { Coefficients }\end{array} \\
\text { Beta }\end{array}$ & $\mathrm{t}$ & Sig. & \multicolumn{3}{|c|}{ Correlations } & \multicolumn{2}{|c|}{$\begin{array}{c}\text { Collinearity } \\
\text { Statistics }\end{array}$} \\
\hline \multirow{4}{*}{1} & Board Size & .175 & .130 & .246 & 1.347 & .192 & .347 & .276 & .213 & .747 & 1.339 \\
\hline & Independent & .014 & .067 & .037 & .202 & .842 & .194 & .043 & .032 & .742 & 1.348 \\
\hline & Culture & .182 & .279 & .116 & .654 & .520 & -.003 & .138 & .103 & .797 & 1.254 \\
\hline & Diversity & -.471 & .148 & -.589 & -3.183 & .004 & -.341 & -.562 & -.503 & .729 & 1.371 \\
\hline
\end{tabular}

The above regression analysis shows a significant relationship between frequency (0.015), diversity (0.004) and ROAA since the significance level is below 5\%. Thus, the null hypothesis is rejected and the alternative hypothesis is accepted.

As for VIF, it shows a low level of collinearity, with the highest value being around 1.8. This means that now there is low multicollinearity among the variables selected for this research.

\section{Regression Equations}

This section deals with the regression equations for the three models mentioned above, and the results are as follows:

Equation 1: ROAA $=0.554+0.022$ frequency meetings +0.023 diversity on board

For every one-unit increase in frequency, the ROAA increases by $0.022 \%$.

For every one-unit increase in diversity on board, the ROAA increases by $0.023 \%$.

After removing the duality of managerial roles from the model because of its high multicollinearity, the following equation will be maintained:

Equation 2: ROAA $=0.557+0.022$ frequency meetings +0.011 diversity on board The following results are obtained then:

For every one-unit increase in frequency meeting, the ROAA is affected by $0.022 \%$. For every one-unit increase in diversity on board, the ROAA is affected by $0.011 \%$. 


\section{THE IMPACT OF CORPORATE GOVERNANCE}

It can be observed here that, after removing the duality from the second equation, the frequency meetings remained constant while the diversity on board changed from 0.023 to 0.011 which means that the percentage dropped from $2.3 \%$ to $1.1 \%$. This means that the duality of managerial roles tends to affect the diversity on the board directly.

After removing the committee variable because of its high multicollinearity, the following equation will be maintained:

Equation 3: ROAA $=0.520+0.015$ frequency meetings +0.004 diversity on board

The following results are obtained then:

For every one-unit increase in frequency of board meetings, the ROAA is affected by $0.015 \%$.

For every one-unit increase in diversity on board, the ROAA is affected by $0.004 \%$.

Therefore, after removing the committee factor from the equation, the frequency of board meetings dropped from $2.2 \%$ to $1.5 \%$, and the diversity on board dropped from $1.1 \%$ to $0.4 \%$. This means that committee tends to impact both board diversity and the frequency of its meetings since both percentages dropped after removing the committee variable from the regression equation, and this equation is the best fit.

\section{Results and Implications}

Our findings allow formulating assumptions applicable to the corporate governance disclosure model and its impact on financial performance. The hypotheses are based on strong variables which are linked to the model selected for this study. Stemming from the regression tables above, the hypotheses have been validated as follows.

The hypothesis concerning the impact of CEO role duality on financial performance of Lebanese banks has been proved to be insignificant.

The board of directors' performance would be influenced by its leadership structure and whether the positions of a CEO and a Chairman are divided or merged into one. As it has been found in other recent research studies on similar topics, division of positions between a CEO and a chairman is known to influence the relationship between the board executives in a bank and the management team and thereby often impacts bank's efficiency overall. However, the findings of our research show that the duality of CEO and Chairman roles has a negative impact on banks' performance.

The next hypothesis in our study states that "the relationship between board size and financial performance" is insignificant. The board size has shown no relationship with financial performance of the banks in our sample. In addition, our analysis shows that a larger board size leads to the problem of agency cost if most of the members fail to demonstrate trust. Our findings concerning board size and productivity of a bank are varying as is the relationship between board size and competitiveness.

The data set in this study has been limited to the annual reports of 29 banks. However, in Lebanese banks the board size does not impact financial performance since the power lies primarily in the hands of the majority of shareholders. The board members on their side, coordinate their actions with the needs of these shareholders because shareholders have the power to elect the Board.

The following hypothesis states that there is a relationship between board diversity and financial performance, and that this relationship is significant. Our results show that this relation between the board of directors and commercial banks performance in Lebanon is 
statistically significant. Diversity is necessary in the situation when the board is going to make promises. Well-trained and inquisitive minds may see different things differently, and this can often be very beneficial when it comes to gathering new ideas. In other words, diversity in the composition helps the Board with diverse thinking.

Our next hypothesis states "There is a relationship between frequency of meetings and financial performance" and that this relationship is significant. The results show that meetings frequency and financial performance are statistically significantly related. Frequency of meetings tends to strengthen transparency and accountability among the board of directors. In quite many cases, the corporate governance framework is usually left to the board of directors, thus, they determine what corporate governance policy would be.

\section{Research Limitations}

Due to time limitations, other variables important for corporate governance were not examined in our study. This concerns some of the important factors, actually, like audit committee, risk committee, remuneration committee, and compliance committee, none of them have been studied in this research. They were grouped into one variable and thus addressed in general.

Furthermore, banks' financial performance is affected by other aspects of management, apart from just and virtuous corporate governance process, namely, economic, legal, political environment and various social issues too.

In this study, the researcher has implemented the quantitative methodology and has been operating secondary data since all the data were borrowed from the annual reports of the selected Lebanese banks for the year 2018. This is considered to be a major limitation in this research since the research as such lacks primary data (such data could have been taken from surveys and interviews, for example).

Moreover, the researcher was not able to implement an actual field study due to time constraints, confidentiality policies in some banks, namely, the impossibility to perform recorded interviews to study the impact of corporate governance variables on the financial performance of banks. This could have been done by means of conducting face-to-face interviews with bank directors to get their opinions and thoughts about corporate governance and its impact on financial performance.

The researcher was not able to address all the components of corporate governance since in this case the research would become very wide, and with many gaps potentially.

More specifically, the CSR variable could be actually studied from many points of view and from different perspectives. It is highly recommended to implement this variable into further research in the same direction, since these days it is considered to be one of the most important variables for any serious analysis of corporate governance.

Finally, this study has addressed 29 banks only, without taking into account the size of these banks. Besides, the data was analyzed for one year - 2018. This is obviously also a limitation of this study.

Bank governance has been a topic of intense policy and academic discussions in the recent years. Many policy documents and academic research have outlined recommendation on how to promote and improve bank governance. In this study, we are also providing suggestions and directions for future research on corporate governance in banks. Namely, 


\section{THE IMPACT OF CORPORATE GOVERNANCE}

further research should investigate other characteristics relating to the "quality" of the board, more specifically - board networking, political and other lobby connections factors.

\section{Recommendations and Future Research Directions}

Banks in Lebanon are obliged to disclose their audited information since investors are expected to use this information as an investment screening tool. Knowing where to invest might be one of the most important decisions for an adult person. Therefore, having open access to banks' annual reports and other important information would surely help in this process.

Looking at the structure of the board of directors in a bank will give you at least a partial understanding of who would be directing your money. If the board is a closed one, there might be additional questions to be asked. For example, are having independent members more trustworthy? It is commonly acknowledged that the larger the number of independent directors on the board, the more unbiased and objective will be the performance of this board. An independent director can often be a "bridge builder" in difficult conversation.

Such independent members are known to be selected based on experience and educational background. Moreover, we need to keep in mind that many companies and organizations (and not only in the banking sector) benefit greatly from employing independent directors, since the latter are often known to be head hunters with a huge network of useful business contacts.

\section{References:}

Adams, R. \& Mehran, H. (2008). Corporate Performance, Board Structure, and Their Determinants In The Banking Industry. Federal Reserve Bank of New York Staff Reports, 330.

Amit, R. \& Villonga, B. (2006). How Do Family Ownership, Control, And Management Affect Firm Value? Journal Of Financial Economics, 80, 385-417.

Basel Committee On Banking Supervision (2003). The New Basel Capital Accord. Available online: https://www.bis.org/bcbs/bcbscp3.htm.

Basel Committee On Banking Supervision (2006). International Convergence Of Capital Measurement And Capital Standards: A Revised Framework Comprehensive Version. Available online at: https://www.bis.org/publ/bcbs128.htm.

Caprio, G., Laeven, L. \& Levine, R. (2007). Governance and Bank Valuation. Journal Of Financial Intermediation, 16 (4), 584-617.

Chidambaran, N.K., Palia, D. \& Zheng, Y. (2008). Corporate Governance and Firm Performance: Evidence From Large Governance Changes. Available online at: https://papers.ssrn.com/sol3/papers.cfm?abstract_id=1108497.

Tarullo, D. K. (2012). Developing Tools for Dynamic Capital Supervision. The Federal Reserve Bank of Chicago Annual Risk Conference, Chicago, Il, April 10. 
Taylor, R. (2006). Worker Board-Level Participation In The Eu-15 Countries, Part I. In: Kluge, N. and Stollt, M. (Eds). The European Company - Prospects For Worker Board Level Participation.

Toçi, V. (2008). Financial Development In Transition Economies With Special Reference To SouthEast Europe And Kosova. PhD Thesis.

Trayler, R. (2007). A Survey Of Corporate Governance In Banking: Characteristics Of The Top 100 World Banks. In: Gup, E. (Ed). Corporate Governance In Banking: A Global Perspective. Cheltenham: Edward Elgar Publishing Limited.

Turner, A. (2009). The Turner Review, A Regulatory Response To The Global Banking Crisis. Rutleger, USA.

Van Osnabrugge, M. (2000). A Comparison Of Business Angel And Venture Capitalist Investment Procedures: An Agency Theory-Based Analysis. International Journal of Entrepreneurial Finance, 2 (2), 89-104.

Williams, J.C. (2012). Bank Regulation In The Post-Crisis World. Available online at: https://ideas.repec.org/p/fip/fedfsp/104.html.

Paper submitted

Paper accepted for publishing

Paper published online
06 May 2021

11 July 2021

31 July 2021 